\title{
PENINGKATAN KEMAMPUAN KOMUNIKASI MATEMATIS DAN KETERAMPILAN BELAJAR SISWA SMP DENGAN MENGGUNAKAN PENDEKATAN CONTEXTUAL TEACHING AND LEARNING
}

\author{
Laelasari $^{1}$, Euis Eti Rohaeti ${ }^{2}$, Nelly Fitriani ${ }^{3}$ \\ 1,2,3 IKIP Siliwangi, Jl. Terusan Jendral Sudirman. Cimahi \\ 1.
}

\begin{abstract}
The purpose of this study is to examine how the improve mathematical communication ability of students in learning using contextual approach. The research method used in this study is a quasiexperimental method, with two different classes taken, where the first class gets the learning with the Contextual Approach and the second class using ordinary learning. The population is all students in one of the islamic junior hight schools in Cimahi city with a sample taken two classes. Both classes were given pretest and early questionnaires to determine their initial ability, then the experimental class was given learning with the contextual approach and the control class was given regular learning, and at the end of both classes were given postes that will on though to use help Software SPSS 17.0 for Windows. Analysis using Product Moment Pearson. The results showed a significan students in learning mathematics.
\end{abstract}

Keywords: Mathematical Communication, Study Skills, Contextual Teaching and Learning Approach

\begin{abstract}
Abstrak
Tujuan dalam riset ini adalah untuk menelaah bagaimana peningkatan kemampuan komunikasi matematis dan keterampilan siswa menggunakan pembelajaran Contextual Teaching and Learning. Desain riset yang digunakan saat bereksplorasi ini yaitu desain kuasi eksperimen, dengan diambil dua kelas yang berbeda, dimana kelas pertama mendapatkan pengkajian bersama model pembelajaran Contextual Teaching and Learning serta kelas kedua memakai pengkajian umum. Populasinya merupakan seluruh siswa pada salah satu SMP di Bandung Barat dengan sampel yang diambil dua kelas. Kedua kelas dibagikan pretes serta kuesioner asal untuk melihat keterampilan asal mereka, kemudian pada kelompok penelitian disampaikan pengkajian menggunakan penerapan Contextual Teaching and Learning serta kelompok dominasi diberikan pembelajaran biasa, dan di akhir kedua kelas diberikan postes kemudian di olah menggunakan bantuan Software SPSS 17.0 for Windows. Hasil penelitian menunjukkan adanya peningkatan yang signifikan siswa seraya pengkajian Contextual Teaching and Learning.
\end{abstract}

Kata Kunci: Komunikasi Matematis, Keterampilan Siswa, Pembelajaran Contextual Teaching and Learning

How to cite: Laelasari,LS., Rohaeti, EE., \& Fitriani, NF. (2018). Peningkatan Kemampuan Komunikasi Matematis dan Keterampilan Belajar Siswa SMP dengan Menggunakan Pendekatan Contextual Teaching and Learning. JPMI - Jurnal Pembelajaran Matematika Inovatif, X (X), XX-XX. 


\section{PENDAHULUAN}

Matematika adalah suatu pengetahuan yang besar digunakan untuk aktivitas sehari-hari. Berguna sebagai masyarakat lumrah atau sebagai individual tersendiri. Sebagai masyarakat lumrah matematika dimanfaatkan untuk semua transaksi dan semua segi aktivitas pengetahuan ilmu hitung yang dijalankan. Matematika merupakan salah satu ilmu dasar yang berkembang pesat, baik materi maupun kegunaannya. Matematika dikenal sebagai ilmu dedukatif, karena setiap metode yang digunakan dalam mencari suatu kebenaran adalah dengan menggunakan metode deduktif, sedangkan dalam ilmu alam dengan menggunakan metode induktif atau eksperimen.

Berdasarkan hal tersebut, suatu keterampilan yang perlu dimiliki oleh murid yaitu keterampilan berkomunikasi. Menurut Guerreiro (2008), Komunikasi matematika adalah suatu alat dalam transfer pengetahuan matematika atau sebagai dasar dalam membentuk pengetahuan matematika.

Kenyataan dilapangan menunjukkan bahwa keterampilan komunikasi matematika siswa masih tergolong rendah. Hal ini sejalan dengan hasil survey Programme for International Student Assessment (PISA) studi yang dilakukan oleh Organisasi Kerja Sama Ekonomi dan Pembangunan (OECD) terhadap anak usia 15 tahun pada tahun 2015, menempatkan kemampuan matematika pelajar Indonesia ada di peringkat ke-63 dari 72 negara. Capaian tersebut kalah jauh dibandingkan dengan negara-negara di Asia Tenggara.

Tujuan pembelajaran matematika adalah tujuan dari suatu proses interaksi antara guru dan siswa dalam kegiatan belajar mengajar dalam rangka mencapai tujuan pendidikan yang memiliki kemampuan intelek dan karakter, keterampilan melahirkan sebuah abstraksi, membangun fakta, mengartikan sebuah pikiran dan afirmasi matematika, mengkoneksikan buah pikiran bersama ikon, grafik, skema dan instrumen berbeda bagi penjelasan ataupun masalah, serta mempunyai perilaku menghormati faedah ilmu hitung dalam kehidupan, yakni mempunyai rasa gemar pengetahuan, kepedulian, serta hasrat dalam mengamati matematika, dan tindakan gigih pada penanggulangan sebuah persoalan.

Banyak aspek yang memicu masih rendahnya keterampilan komunikasi matematika yang dimiliki siswa di Indonesia. Salah satu pemicunya yaitu desain pengkajian yang belum akurat yang mencakup keterampilan, kemampuan menulis, membaca, diskusi, dan wacana. Kegiatan pembelajaran yang belum akurat dan siswa yang kurang aktif menyebabkan kegiatan pembelajaran menjadi kurang efektif dan kurang efisien.

Untuk itu diperlukan salah satu pendekatan pengkajian matematika yang dianggap dapat memotivasi siswa untuk berperan aktif dalam suatu pembelajaran yaitu dengan menggunakan pembelajaran Contextual Teaching and Learning. Selain itu, keterampilan komunikasi matematika siswa SMP yang menggunakan pendekatan Contextual Teaching and Learning menunjukan bahwa peningkatan keterampilan komunikasi siswa yang belajar dengan menggunakan pembelajaran Contextual Teaching and Learning lebih signifikan dibandingkan dengan pembelajaran konvensional dan proses penyelesaian jawaban siswa pun di kelas menjadi lebih tinggi (Setiawati, 2013).

Menurut Greenes, C. \& Schulman (Armiati, 2009) menyatakan bahwa pentingnya komunikasi matematis karena beberapa hal yaitu untuk menyatakan ide melalui percakapan, tulisan, demonstrasi, dan melukiskan secara visual dalam tipe yang berbeda; memahami, 
menginterpretasikan dan mengevaluasi ide yang disajikan dalam tulisan atau dalam bentuk visual; mengkonstruksi, menginterpretasi, dan mengaitkan berbagai bentuk representasi ide dan hubungannya; membuat pengamatan dan konjektur, merumuskan pertanyaan, membawa dan mengevakuasi informasi; menghasilkan dan menyatakan argumen secara persuasif.

Sumarmo(Surya \& Rahayu, 2014) menyatakan bahwa kemampuan yang tergolong dalam komunikasi matematika diantaranya adalah (1) kemampuan menyatakan suatu situasi, gambar, diagram atau benda nyata ke dalam bahasa, symbol, ide, atau model matematika, (2) menjelaskan ide, situasi, dan relasi matematika secara lisan atau tulisan, (3) mendengarkan, berdiskusi, dan menulis tentang matematika, (4) membaca dengan pemahaman suatu representasi matematika tertulis, (5) membuat konjektur, merumuskan definisi, dan generalisasi, dan (6) mengungkapkan kembali suatu uraian atau paragrap matematika dalam bahasa sendiri.

Berdasarkan ulasan diatas, maka peneliti melaksanakan sebuah penelitian dengan judul “ Peningkatan Kemampuan Komunikasi Matematis dan Keterampilan Belajar Siswa SMP dengan Menggunakan Pendekatan Contextual Teaching and Learning". Adapun rumusan masalahnya adalah:

1. Bagaimana peningkatan kemampuan komunikasi matematis dan keterampilan siswa dengan menggunakan pendekatan Contextual Teaching and Learning?

2. Apakah terdapat pengaruh kemampuan komunikasi matematis dan keterampilan siswa dengan menggunakan pembelajaran Contextual Teaching and Learning?

\section{METODE}

Metode dari eksplorasi ini yaitu desain kuasi eksperimen, dimana kelas eksperimen mendapat pendekatan pembelajaran Contextual Teaching and Learning sedangkan pada kelas kontrol memakai pengkajian umum yang masing-masing akan dialokasikan sebelum tes dan sesudah tes dengan perangkat yang sama. Instrumen yang digunakan adalah seperangkat soal tes berbentuk uraian. Data hasil penelitian dianalisis dengan uji korelasi pada Software SPSS 17.0 for windows.

\section{Soal Tes Keterampilan Komunikasi Matematis}

Instrumen soal yang digunakan berupa soal uraian pada materi segitiga dan segiempat yang telah teruji validitasnya, dimana setiap soal memiliki satu indikator komunikasi matematis. Adapun indikator komunikasi matematis menurut NCTM (dalam Fachrurazi: 2011) adalah sebagai berikut:

(1) Menghubungkan benda nyata, gambar, dan diagram ke dalam ide matematika,

(2) Membuat konjektur, menyusun argumen, merumuskan definisi dan generalisasi,

(3) Menjelaskan ide, situasi dan relasi matematika secara lisan atau tulisan,

(4) Kemampuan mengekspresikan ide-ide matematis melalui lisan, tulisan, dan mendemonstrasikannya serta menggambarkannya secara visual,

(5) Kemampuan memahami, menginterpretasikan, dan mengevaluasi ide-ide matematis baik secara lisan, tulisan, maupun dalam bentuk visual lainnya.

Menurut Muslich (2012) pembelajaran Contextual Teaching and Learning melibatkan tujuh komponen utama yaitu:

(1) Kontruktivisme (Contructivism);

(2) Inkuiri (Inquiry); 
(3) Bertanya (Questioning);

(4) Masyarakat Belajar (Learning Community);

(5) Pemodelan (Modelling);

(6) Refleksi (Reflection);

(7) Penilaian Autentik (Authentic Assessment);

\section{HASIL DAN PEMBAHASAN}

\section{Hasil}

\section{Deskripsi dan analisis Kesulitan siswa dalam menyelesaikan soal - soal keterampilan komunikasi matematis}

Pemaparan hasil jawaban soal tes keterampilan komunikasi matematis murid di kelas dapat dilihat dengan menggunakan presentase skor terhadap SMI yaitu dengan membandingkan nilai rata-rata jawaban perbutir soal dengan skor maksimal perbutir soal dikali 100 persen, dengan kriteria sebagai berikut:

a. Jika presentase skor terhadap SMI lebih dari 50\% maka murid tersebut tidak mengalami kesulitan dalam menyelesaikan soal-soal keterampilan komunikasi matematis;

b. Jika presentase skor terhadap SMI kurang dari 50\% maka murid tersebut mengalami kesulitan dalam menyelesaikan soal-soal keterampilan komunikasi matematis.

Untuk memberikan skor terhadap jawaban dari test, berikut ini adalah pedoman penskoran tes komunikasi matematis Holistik Scoring Rubrics yang diadaptasi oleh Lindawati (2010). Kriteria skor untuk test ini dapat dilihat pada tabel berikut:

Tabel 1. Penskoran untuk Perangkat Tes Keterampilan Komunikasi Matematis

Tingkat Komunikasi

Kriteria Penilaian

Nilai

\begin{tabular}{|c|c|c|}
\hline $\begin{array}{l}\text { Komunikasi } \\
\text { sepenuhnya }\end{array}$ & $\begin{array}{l}\text { Semua penjelasan dengan menggunakan gambar, fakta, } \\
\text { dan hubungan dalam menyelesaikan soal, dijawab dengan } \\
\text { lengkap, jelas dan benar }\end{array}$ & 4 \\
\hline Komunikasi sebagian & $\begin{array}{l}\text { Semua penjelasan dengan menggunakan gambar, fakta, } \\
\text { dan hubungan dalam menyelesaikan soal, dijawab dengan } \\
\text { lengkap dan benar namun mengandung sedikit kesalahan }\end{array}$ & 3 \\
\hline Miskonsepsi sebagian & $\begin{array}{l}\text { Penjelasan konsep, ide atau persoalan dari suatu gambar } \\
\text { yang diberikan dengan kata-kata sendiri dalam bentuk } \\
\text { penulisan kalimat secara matematik masuk akal, } \\
\text { melukiskan gambar namun hanya sebagian yang benar }\end{array}$ & 2 \\
\hline Miskonsepsi & $\begin{array}{l}\text { Hanya sedikit dari penjelasan konsep, ide atau persoalan } \\
\text { dari suatu gambar yang diberikan dengan kata-kata sendiri } \\
\text { dalam bentuk penulisan kalimat secara matematik dan } \\
\text { gambar yang dilukis yang benar }\end{array}$ & 1 \\
\hline Tidak berkomunikasi & Tidak ada jawaban/salah menginterpretasikan & 0 \\
\hline
\end{tabular}

SMI Keterampilan Komunikasi Matematis adalah 20 
Tabel 2. Presentase Skor Terhadap SMI Hasil Tes Kemampuan Pemahaman Matematis

\begin{tabular}{clcc}
\hline No soal & \multicolumn{1}{c}{ IndikatorKemampuanKomunikasiMatematis } & Rata-rata & $\%$ \\
\hline 1 & $\begin{array}{l}\text { Menghubungkan benda nyata, gambar, dan diagram ke } \\
\text { dalam ide matematika }\end{array}$ & 2,83 & $70,75 \%$ \\
2 & $\begin{array}{l}\text { Membuat konjektur, menyusun argumen, merumuskan } \\
\text { definisi dan generalisasi }\end{array}$ & 2,62 & $65,50 \%$ \\
3 & $\begin{array}{l}\text { Menjelaskan ide, situasi dan relasi matematika secara } \\
\text { lisan atau tulisan }\end{array}$ & 2,43 & $60,75 \%$ \\
4 & $\begin{array}{l}\text { Kemampuan mengekspresikan ide-ide matematis } \\
\text { melalui lisan, tulisan, dan mendemonstrasikannya serta } \\
\text { menggambarkannya secara visual }\end{array}$ & 1,45 & $36,25 \%$ \\
& $\begin{array}{l}\text { Kemampuan memahami, menginterpretasikan, dan } \\
\text { mengevaluasi ide-ide matematis baik secara lisan, } \\
\text { tulisan, maupun dalam bentuk visual lainnya }\end{array}$ & 0,92 & $23,00 \%$ \\
\hline & Skor & 1,89 & $47,25 \%$ \\
\hline
\end{tabular}

Hasil penelitian yang disajikan pada Tabel 1 diatas soal keterampilan komunikasi matematis pada soal nomor 4 dan 5 dapat dilihat bahwa presentasenya kurang dari 50\%, sesuai dengan criteria yang telah dijabarkan diatas, maka siswa mengalami kesulitan dalam menyelesaikan soal-soal keterampilan komunikasi matematis.

Kesalahan siswa dalam mengerjakan soal kemampuan komunikasi matematis pada indikator nomor (4) Kemampuan mengekspresikan ide-ide matematis melalui lisan, tulisan, dan mendemonstrasikannya serta menggambarkannya secara visual, dengan soal sebagai berikut: "Taman berbentuk trapesium sama kaki dengan panjang sisi-sisi sejajarnya $(\mathrm{x}+4) \mathrm{m}$ dan $(3 \mathrm{x}+2) \mathrm{m}$. Jika jarak kedua garis sejajar $2 \mathrm{x} \mathrm{m}$ dan luas taman $180 \mathrm{~m}^{2}$, keliling taman adalah?"

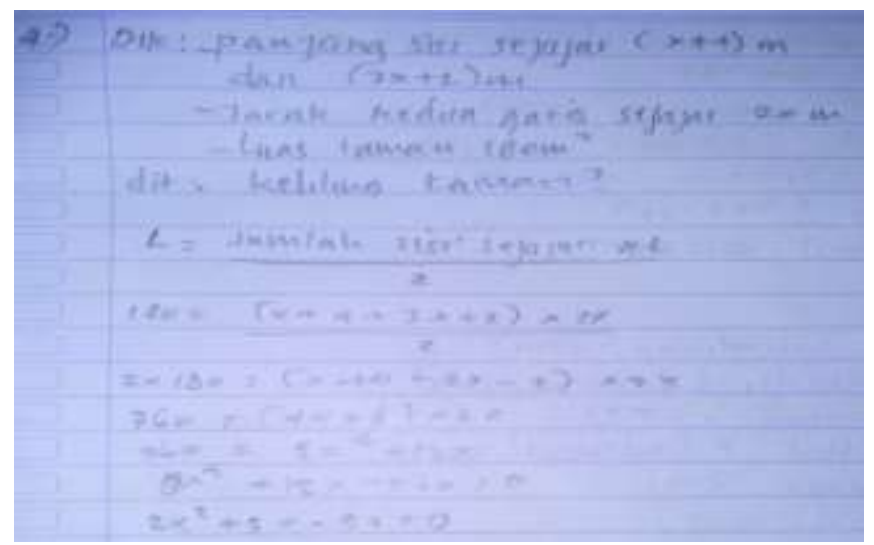

Gambar 1. Kesalahan Murid Pada Soal Nomor 4

Dari jawaban murid di atas dapat dianalisis letak kesalahannya yaitu mereka cenderung kurang lengkap dalam menjawab soal tersebut sehingga tidak dapat menyelesaikan soal dengan tepat.

Kesalahan murid dalam mengerjakan soal kemampuan komunikasi matematis pada indikator nomor (5) Kemampuan memahami, menginterpretasikan, dan mengevaluasi ide-ide matematis baik secara lisan, tulisan, maupun dalam bentuk visual lainnya, dengan soal sebagai berikut:

"Perbandingan sudut-sudut dalam sebuah segitiga adalah $3: 5: 7$. Besar sudut terbesar dari segitiga tersebut adalah?" 


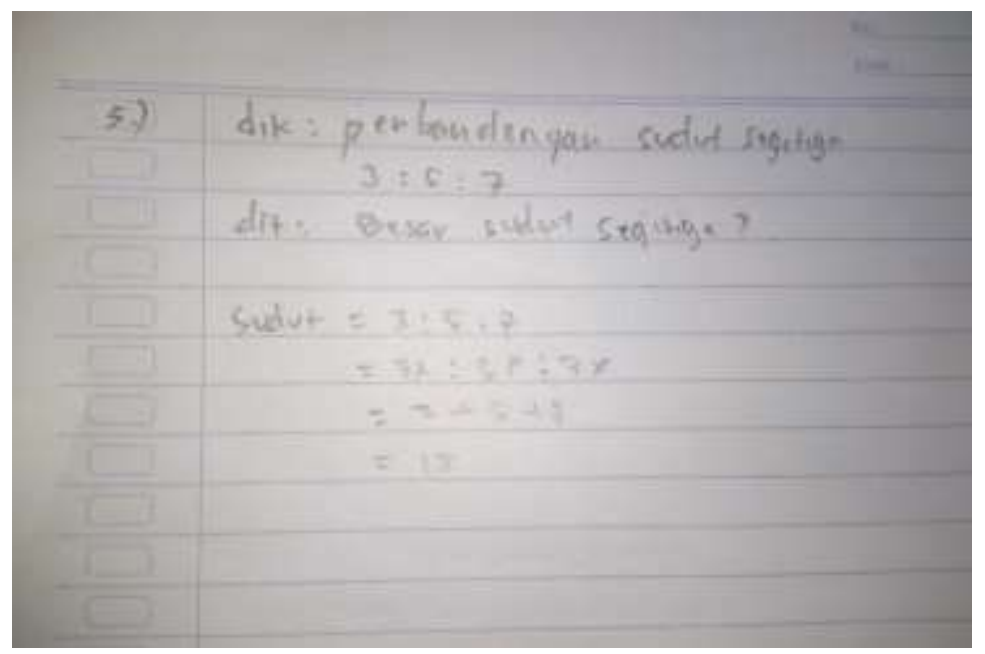

Gambar 2. Kesalahan Siswa Pada Soal Nomor 5

Dari jawaban murid dapat dianalisis bahwa mereka belum paham dengan apa yang dimaksud dengan pertanyaan yang ada pada soal, dan tidak faham dengan sudut-sudut segitiga.

\section{Deskripsi Hasil dan Analisis Keterampilan Komunikasi Matematis}

Pemaparan hasil jawaban angket skala keterampilan komunikasi matematis murid di kelas dapat dilihat dengan presentase skor terhadap SMI yaitu membandingkan nilai rata-rata jawaban perindikator dengan skor maksimal perbutir pernyataan dikali 100 persen, dengan kriteria sebagai berikut:

a. Jika presentase skor terhadap SMI lebih dari 50\% maka murid tersebut terampil berkomunikasi dengan kemampuan yang dimilikinya;

b. Jika presentase skor terhadap SMI kurang dari 50\% maka murid tersebut tidak terampil berkomunikasi dengan kemampuan yang dimilikinya.

Tabel 3. Hasil Tes Keterampilan Komunikasi Matematis

\begin{tabular}{|c|c|c|c|}
\hline No soal & IndikatorKeterampilanKomunikasiMatematis & Rata-rata & $\%$ \\
\hline 1 & Terampil kepada kemampuan sendiri & 1,57 & $39,25 \%$ \\
\hline 2 & Bertindak mandiri dalam mengambil keputusan & 2,40 & $60,00 \%$ \\
\hline 3 & Mengeluarkan ide-ide matematik & 2,56 & $64,00 \%$ \\
\hline 4 & $\begin{array}{l}\text { Mampu mengubah soal kata-kata kedalam symbol dan } \\
\text { sebaliknya }\end{array}$ & 2,15 & $53,75 \%$ \\
\hline & Skor & 2,18 & $54,50 \%$ \\
\hline
\end{tabular}

SMI Skala Kepercayaan Diri Siswa adalah 80

Berdasarkan Tabel 3 diatas terlihat hasil presentase hasil tes keterampilan komunikasi matematis siswa pada indikator nomor 1 berada dibawah 50\% maka dapat disimpulkan bahwa masih ada siswa yang tidak terampil akan kemampuan yang dimilikinya. 


\section{Uji Korelasi antara Kemampuan Komunikasi Matematis dan Keterampilan Siswa}

Selanjutnya dilakukan uji korelasi untuk mengetahui hubungan antara kemampuan komunikasi matematis dengan tingkat keterampilan siswa, berikut tabel hasil pengujiannya.

Tabel 4. Hasil Correlations

\begin{tabular}{llrr}
\hline & & $\begin{array}{l}\text { Kemampuan } \\
\text { Komunikasi Matematis }\end{array}$ & \multicolumn{2}{c}{$\begin{array}{l}\text { Keterampilan } \\
\text { Siswa }\end{array}$} \\
\hline Kemampuan & Pearson & 1 & $.859^{* *}$ \\
Komunikasi Matematis & Correlation & & \\
& Sig. (2-tailed) & 18 & .000 \\
& N & $.859^{* *}$ & 18 \\
Keterampilan Siswa & Pearson & & 1 \\
& Correlation & .000 & \\
& Sig. (2-tailed) & 18 & 18 \\
\hline
\end{tabular}

Hasil penelitian pada tabel 4 nilai signifikansi dari output diatas terlihat bahwa kemampuan komunikasi matematis dengan tingkat keterampilan siswa memiliki nilai signifikansi 0,000 artinya nilai tersebut $<0,05$ maka dapat disimpulkan bahwa terdapat hubungan antara kemampuan komunikasi matematis dengan keterampilan siswa dan dapat dilihat pula dari nilai pearson correlation adalah 0,859 artinya dapat disimpulkan bahwa keterampilan siswa berpengaruh besar terhadap kemampuan komunikasi matematis.

\section{Pembahasan}

Berdasarkan hasil analisis data penelitian dapat dilihat pada Tabel 2 diatas soal kemampuan komunikasi matematis pada soal nomor 1 dengan indikator menghubungkan benda nyata, gambar, dan diagram ke dalam ide matematika, presentase ketuntasannya 70,75\%. Pada soal nomor 2 dengan indikator membuat konjektur, menyusun argumen, merumuskan definisi dan generalisasi, presentase ketuntasannya $65,50 \%$. Soal nomor 3 dengan indikator menjelaskan ide, situasi dan relasi matematika secara lisan atau tulisan, presentase ketuntasannya $60,75 \%$. Soal nomor 4 dengan indikator kemampuan mengekspresikan ide-ide matematis melalui lisan, tulisan, dan mendemonstrasikannya serta menggambarkannya secara visual, presentase ketuntasannya 36,25\%. Soal nomor 5 dengan indikator kemampuan memahami, menginterpretasikan, dan mengevaluasi ide-ide matematis baik secara lisan, tulisan, maupun dalam bentuk visual lainnya, presentase ketuntasannya $23,00 \%$. Sejalan dengan penelitian yang dilakukan oleh Purwasih (2016) siswa yang memiliki kemandirian akan berdampak terhadap prestasi belajarnya dan meningkat pula kemampuan matematisnya.

Dari hasil penjabaran diatas terlihat bahwa presentase pada indikator nomor 4 dan 5 berada di bawah $50 \%$ dan pada indikator nomor 1, 2 dan 3 berada diatas $50 \%$. Dari 5 soal yang disajikan ternyata terdapat 2 soal yang membuat siswa masih kesulitan untuk mengerjakannya. Menurut Purwasih (2015) siswa yang memiliki kemampuan pemecahan masalah menunjukan siswa tersebut memiliki kemampuan memberikan solusi dalam penyelesaian persoalan matematika.

Dari jawaban siswa pada Gambar 1, terlihat bahwa siswa terlalu ceroboh dalam mengerjakan soal tersebut sehingga siswa tidak dapat menyelesaikan prosedur tahapan jawaban dari soal 
tersebut. Hal tersebut sesuai dengan Wiyartimi dkk (2010: 91) mengemukakan bahwa kesalahan karena kecerobohan disebabkan karena kurangnya pemahaman siswa pada materi lain yang berhubungan dengan perhitungan. Pada Gambar 2 terlihat hasil jawaban siswa tidak memahami pertanyaan yang ada pada soal, dan tidak faham dengan materi pada soal tersebut. Menurut Eva (2011: 10) dalam karyanya menjelaskan bahwa kesalahan dalam matematika dapat diartikan sebagai suatu pemahaman yang kurang tepat dalam mempelajari suatu konsep matematika atau menyimpang dari aturan matematika.

Selanjutnya adalah analisis hubungan antara kemampuan komunikasi matematis dengan keterampilan siswa. Berdasarkan hasil uji korelasi dapat disimpulkan bahwa keterampilan siswa berhubungan secara positif terhadap kemampuan komunikasi matematis. Sejalan dengan penelitian yang dilakukan oleh Umar (2012) yang mengkaji tentang membangun komunikasi matematis dalam pembelajaran matematika diperlukan sebuah keterampilan mendalam tentang profil kemampuan komunikasi matematis mahasiswa dalam menyelesaikan masalah matematika. Hal ini terlihat dari nilai untuk kelas kontrol bernilai positif sebesar 0,267 dan nilai korelasi untuk kelas eksperimen sebesar 0,154. Oleh karena itu pembelajaran Contextual Teaching and Learning harus diatasi agar kemampuan komunikasi matematis siswa dapat berkembang dengan baik.

Menurut Nurhadi dalam Rusman (2010: 199) pembelajaran Contextual Teaching and Learning adalah konsep belajar yang membantu guru mengaitkan antara materi yang diajarkannya dengan situasi dunia nyata siswa serta mendorong siswa membuat hubungan antara pengetahuan yang dimilikinya dengan keterampilan dan kemampuan komunikasi dalam kehidupan sehari-harinya.

Berdasarkan hasil penelitian dan pembahasan diatas disimpulkan bahwa pembelajaran Contextual Teaching and Learning berpengaruh terhadap kemampuan komunikasi dan keterampilan siswa.

\section{KESIMPULAN}

Berdasarkan hasil penelitian, secara umum dapat dibuat kesimpulan hasil penelitian sebagai berikut:

1. Terdapat peningkatan kemampuan komunikasi matematis dan keterampilan siswa dengan menggunakan pendekatan Contextual Teaching and Learning

2. Terdapat pengaruh kemampuan komunikasi matematis dan keterampilan siswa dengan menggunakan pendekatan Contextual Teaching and Learning

\section{DAFTAR PUSTAKA}

Armiati. (2009). Komunikasi Matematis dan Pembelajaran Berbasis Masalah. Semnas Matematika UNPAR Bandung.

Eva Wulanningtyas, Melania (2011). Analisis Kesalahan Siswa di Kelas VIII B Sekolah Menengah Pertama Kanisius Pakem dalam Mengerjakan Soal Cerita pada Topik Perbandingan Senilai dan Berbalik Nilai Tahun Ajaran 2011/2012. Yogyakarta: Universitas Sanata Dharma.

Fachrurazi, (2011). Strategi Jitu Mencapai Kesuksesan Belajar. Jakarta: Alex Media 
Komputindo.

Guerreiro, A. (2008). Communication in Mathematics Teaching and Learning. Practices in Primary Education.

Lindawati, S. (2010). Pembelajaran Matematika dengan Pendekatan Inkuiri Terbimbing untuk Meningkatkan Kemampuan Pemahaman dan Komunikasi Matematik Siswa Sekolah Menengah Pertama. Tesis. SPS UPI: Tidak diterbitkan.

Muslich, M. (2012). Pembelajaran Berbasis Kompetensi dan Kontekstual. Jakarta: Bima Aksara .

Purwasih, R. (2016). Peningkatan Kemandirian Belajar Mahasiswa Melalui Pembelajaran Personalized System Of Instruction. Prosiding Seminar Nasional Matematika Dan Pendidikan Matematika Stkip Siliwangi. Vol. 4, 190.

Purwasih, R. (2015). Peningkatan Kemampuan Pemahaman Matematis dan Self Confidence Siswa MTS di Kota Cimahi Melalui Model Pembelajaran Inkuiri Terbimbing. Didaktik, 9(1), 16-25.

Rusman. (2012). Model-Model Pembelajaran Mengembangkan Profesionalisme Guru. Jakarta: PT Raja Grafindo Persada.

Setiawati, D., Syahputra, E. (2013). Perbedaan Kemampuan Pemecahan Masalah dan Komunikasi Matematis Siswa antara Pendekatan Contextual Teaching and Learning dan Pembelajaran Konvensional pada Siswa Kelas X SMK Negeri 1 Bireuen. Paradigma Jurnal Pendidikan Matematika, Vol. 6, No.I.

Sumarmo. (2005). Pengembangan Berfikir Matematik Tingkat Tinggi Siswa SLTP dan SMU Serta Mahasiswa Strata Satu (S1) Melalui Berbagai Pendekatan Pembelajaran. Bandung: Universitas Pendidikan Indonesia.

Surya, E., \& Rahayu, R. (2014). Peningkatan Kemampuan Komunikasi dan Pemecahan Masalah Matematis Siswa SMP Ar-Rahman Percut melalui Pembelajaran Kooperatif Tipe Student Teams Achievement Division (STAD). Medan: Unimed Press.

Umar, Wahid. (2012). Membangun Kemampuan Komunikasi Matematis dalam Pembelajaran Matematika. Infinity. Jurnal Ilmiah Program Studi Matematika STKIP Siliwangi Bandung. Vol 1, No.1 Februari 2012.

Wiyartimi, dkk. (2010). Diagnosis Kesulitan Belajar Matematika Siswa pada Materi Trigonometri Rumus-Rumus. JMAP 9 (2): 89-99. 
856 Laelasari, Rohaeti \& Fitriani, Peningkatan Kemampuan Komunikasi Matematis.... 